\title{
EFFICIENT CAPACITANCE SENSING FOR WIRELESS HEALTH MONITORING SYSTEMS
}

\author{
Nurul Arfah Che Mustapha*, A.H.M. Zahirul Alam, Sheroz Khan, \\ AND AMELIA WONG AZMAN \\ Department of Electrical and Computer Engineering, \\ Faculty of Engineering, International Islamic University Malaysia, \\ Jalan Gombak, 53100, Kuala Lumpur, Malaysia. \\ *corresponding author: n.c.2013@ieee.org
}

(Received: $5^{\text {th }}$ Jan. 2016; Accepted: $26^{\text {th }}$ Mar. 2016; Published on-line: $30^{\text {th }}$ Nov. 2016)

\begin{abstract}
This paper presents a low power capacitance to voltage converter (CVC) circuit using two differential amplifier circuits, two Schottky rectifier diodes constructed in a symmetrical manner and combined with instrumentation amplifier circuits. The differential capacitance to voltage simulation work has been realized with inexpensive discrete components. Energy from a combination of solar, vibration and heat sources is expected to charge the capacitance circuit. A constant DC voltage of $3 \mathrm{~V}$ has been used to power the CVC circuit in this work. Simulation has shown that the converter circuit consumes $3.9 \mathrm{~mW}$ of total power, and operates at $40 \mathrm{kHz}$ using a $400 \mathrm{mV}$ excitation signal. The circuit is able to detect changes of capacitance from $4-12.5 \mathrm{pF}$ using a reference capacitance of $5 \mathrm{pF}$. A sensitivity of $0.132 \mathrm{mV}$ for $1 \mathrm{fF}$ capacitance change has been observed in the circuit. Using discrete components with same component values as in previous work, this circuit has shown more sensitivity in capacitance detection with less power consumption.
\end{abstract}

ABSTRAK: Kertas kerja ini membentangkan berkenaan litar penukar kapasitor voltan (CVC) berkuasa rendah dengan menggunakan dua litar penguat pembezaan, dua diod Schottky, dibina secara simetri dan digabungkan dengan litar instrumen penguat. Kerja simulasi litar pembezaan kapasitor voltan ini telah dibangunkan dengan menggunakan komponen diskrit murah. Kombinasi tenaga dari solar, getaran dan haba digunakan untuk memberi sumber tenaga kepada litar kapasitor. Voltan DC tetap sebanyak $3 \mathrm{~V}$ telah digunakan sebagai sumber tenaga CVC kerja ini. Menerusi simulasi, didapati litar penukaran ini menjana $3.9 \mathrm{~mW}$ daripada jumlah tenaga, beroperasi pada kadar $40 \mathrm{kHz}$ dengan menggunakan $400 \mathrm{mV}$ signal pemula. Litar ini mampu mengesan penukaran kapasitan dari $4-12.5 \mathrm{pF}$ menggunakan kapasitan rujukan $5 \mathrm{pF}$. Tahap kepekaan pada $0.132 \mathrm{mV}$ bagi tiap $1 \mathrm{fF}$ perubahan kapasitan telah dikesan menggunakan litar ini. Dengan menggunakan komponen diskrit dan nilai komponen yang sama seperti kerja sebelumnya, litar ini telah berhasil menunjukkan tahap kepekaan yang lebih sensitif dalam mengesan perubahan kepekaan dengan nilai penggunaan kuasa yang berkurangan.

KEYWORDS: energy harvester; differential capacitance sensing; capacitance measurement system; health monitoring system

\section{INTRODUCTION}

Recently, demand for wireless communications appliances has been on the rise. The wireless data communication approach, though not as reliable as the wired approach, is a preferable choice in many industrial applications where space and accessibility are not always guaranteed. Designers of such appliances began searching for alternative ways to 
power their designs including opting for the use of the energy harvesting principle instead of the conventional wired or battery-powered methods. One of the appliances that will benefit the most from this research is smart wireless sensor technology.

Smart wireless sensors are part of an emerging sensor environment with essential features such as on-board micro-processors, sensing capabilities, wireless communication, battery-less power, and low-cost maintenance. Previously, conventional wireless sensor nodes have utilized batteries as the main power supply. Unfortunately, some of the known issues when using batteries occur during battery replacement, including interruption of services, loss of valuable time, tedious maintenance work, and additional operational costs during maintenance. Therefore, it is favorable, even crucial, for smart sensor wireless systems to be equipped with self-generated power systems for a sustainable power supply. The self-generated power sources could come from any of the ambient sources that can be found in an industrial environment such as vibration, heat, water, human activity, and wind.

\section{BACKGROUND AND MOTIVATION}

Capacitive measuring systems represent an important technology in transducer systems. The motivation behind using capacitive measuring system is that they provide easy and efficient conversion of changes in a parameter of interest into a wide range of capacitance changes, which are in turn changed into proportional voltage or frequency changes. The advantage here is that these conversions take place without functionality loss compared to other systems, such as inductive systems. Using a source of vibrations and converting mechanical energy to electrical energy provides a promising solution for powering wireless sensor nodes. This method has been comprehensively researched in recent years. Among the vibrations transducer methods used are piezoelectric, electromagnetic, and the capacitive-inductive or capacitive-electrostatic approach [1-4]. Each method has its own advantages and disadvantages, but none can currently provide a solution with a sufficient power output $[5,6]$. The selection of converting device is dependent on either capturing or measuring the available physical parameters such as displacement, velocity and acceleration.

Many wireless electronic devices such as tiny network wireless sensor nodes, wireless health monitoring systems, as well as consumer products such as smart phones have severely constrained power sources [1,7]. The main challenge in the mentioned devices is largely with the effort to sustain a continuous and reliable power supply without the presence of batteries, which either require charging or replacement with a new battery altogether at the expense of cost and time. Smart wireless powered sensors have been proven to be cost effective and an alternative solution to this problem when realized properly, particularly in electronic devices used in applications such as in Structural Health Monitoring (SHM) systems, monitoring forest fires, medical implants, ocean pollution spillages, etc.

In this work, a capacitive sensor-based circuitry for wireless sensor devices is proposed using a hybrid energy harvesting technique, shown in Fig. 1, where the energy generated is expected to be able to operate in the wireless frequency range with sufficient output power for the wireless sensor nodes. This work focuses on deriving energy from vibrations complemented by thermal energy. The method of generating energy is based on the wireless sensor network characteristic of lowering the response frequency, maximizing the bandwidth of frequency operation, lowering power consumption, and generating voltage. 


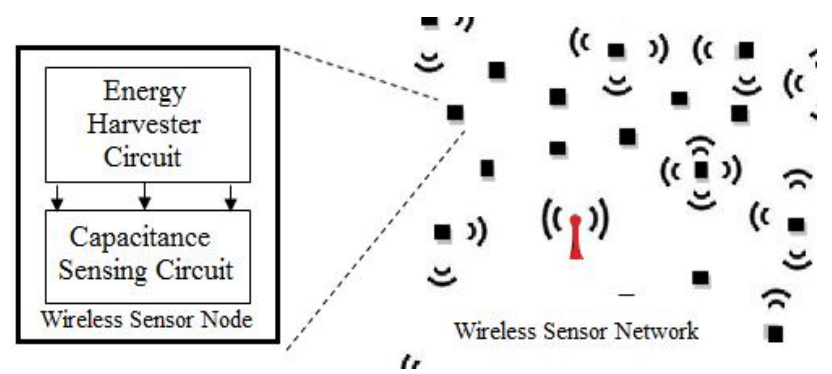

Fig. 1: Topology of the proposed capacitance sensing wireless sensor node.

\section{STATE OF THE ART}

It is important to reduce a device's power requirement regardless of whether the power is from an energy harvester or from batteries. This is especially true with portable devices such as computing devices, medical implants, military equipment and wireless sensor networks. Most of current research has focused on the microwatt to hundred milliWatt range of power output energy harvesters [4, 8]. The smaller the device size is, the smaller its power requirement becomes. When power requirements are at a minimum in modern devices, they are suited to harvesting energy from their environment from such sources as vibration, heat, and light. However, few research attempts have been made on medium range power output that would be especially suitable for mobile applications using energy harvester techniques [2]. Efficiency of the power output of energy harvesters is significantly limited by the effectiveness of the energy converting transducers used for energy conversion. Research in [9] has stated that power requirement must be scaled down to a size of less than $1 \mathrm{~cm}^{3}$ and the power consumption goal should be below $100 \mu \mathrm{W}$. It is necessary for the wireless sensor network to be operated in the range of at least $100 \mu \mathrm{W}$ to $100 \mathrm{~mW}[10,11]$.

Portable electronic gadgets such as lightweight mobile smart phones, capacitive multi-touch screen tablet PCs, and all-in-one-computers, have been extensively developed over the past years $[12,13]$ while the focus on reducing the battery reliance of such devices has been gaining importance. Such mechanisms are being researched in which energy is harvested from means such as vibration, solar, wind, heat, shoe power, water, and oceans. The difference between these techniques lies in the circuit design and the operation principle on which such energy conversion techniques are based. There are three common techniques used in harvesting energy from vibration, these are: capacitive/electrostatic, piezoelectric, and electromagnetic techniques. The capacitance inductive/electrostatic harvesting technique is more frequently considered over other techniques because of its ease of implementation in MEMS and CMOS systems.

In general, the design of energy harvesting device consists of three main components: a micro-generator, a voltage booster, and a storage element [1]. The fact that harvesting devices only produce a very small amount of energy to directly power electronic circuits can become a major drawback for circuit designers and researchers [2, 5]. Some efficient and useful technique should be considered to gather and accumulate this energy or to store the converted electrical energy before the harvested energy can be used to power the wireless sensor devices. Research in [14] has highlighted the importance of investigating environmental conditions before designing a harvester.

Energy profiles from two independent and available energy sources, thermal and solar, have been the focus. However, each harvester has provided a different electrical behavior with thermal supplying a level near $100 \mathrm{mV}$ and solar supplying a few volts. In 
this case, both should supply the same level of energy in order to be combined into a single power supply. Energy management is required for the combination of both solar cells and thermoelectric transducers to reach a high energy yield within a short start-up time, where an independent voltage booster of an available DC/DC converter can be applied to tackle the problem.

Extensive work has been reported [15-19] using the capacitance technique where this technique was suitable for use in wireless application and to source sensor nodes. One of the techniques used in MEMS technology is the capacitive principle. Energy from the environment, such as from the vibration, is used to move a parallel plate spring mass system, which is capable of converting mechanical energy into electrical energy to source the capacitive technique. This capacitive principle requires the charging of the capacitor at all time to ensure the conversion technique. In order to maintain the conversion, these capacitors should be charged with a dedicated electronic switch. However, this technique requires additional complex circuitry and presents relatively high energy losses [15].

Several researchers have highlighted the choice of material for the capacitor plate used. Research in [16] has suggested using a soft polymer for the sensor device in order to replace battery dependency. A Parylene-electrets generator material has also been reported in [17] where this MEMS-friendly material offers a very high surface charge density and has the characteristic of a high-aspect-ratio spring. Consequently, it allows a low resonant frequency with large amplitude - which is much desired in modern applications. However, this electrets technology can cause high costs due to the production and the poling of the dielectric electrets material $[18,19]$. Electrets have also been known for problems with long term stability [15]. In order to avoid the problem caused by the electrets, a different approach of charging the parallel-plate capacitor has been presented in [20], which makes use of two different materials in its work function. Additional electronic circuitry and MEMS technology is, however, much simpler than the electrets technique.

\section{PROPOSED APPROACH}

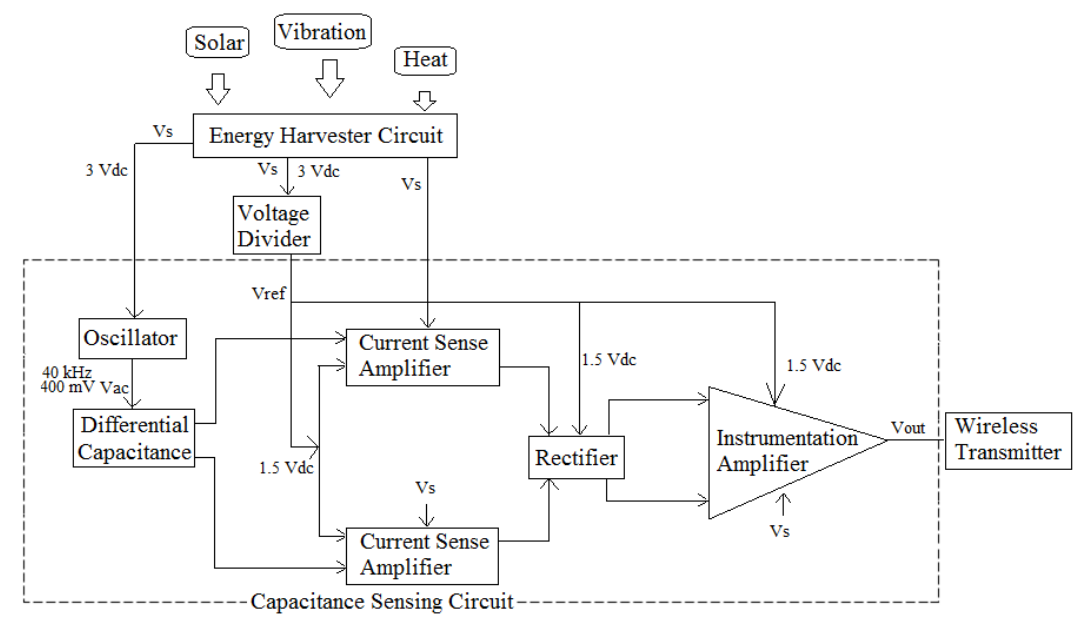

Fig. 2: Block diagram of the proposed capacitance sensing wireless sensor node.

In this work, the capacitance sensor read-out circuit shown in [21] is used for the proposed sensing node architecture in Fig. 2. The differences between the circuit used in 
[21] and this work are; (1) the PMOS diode is replaced with a Schottky diode, (2) the voltage divider is used to generate a single source supplied by the $3 \mathrm{~V}$ supply, generated from an energy harvester circuit to supply all reference signal sources, $\mathrm{V}_{\text {ref }}$, (3) simulation as in Fig. 3 is done using the PSpice simulation tool, based on real components parameters obtained from its datasheet such that it can be easily constructed using commerciallyavailable discrete components, and (4) a lower frequency of $40 \mathrm{kHz}$ is used in this simulation.

\section{METHODOLOGY}

The CVC circuit shown in Fig. 3 has five main blocks namely, the excitation source, the differential capacitance, the differential amplifiers, the rectifier circuit and the instrumentation amplifier circuit. The excitation amplitude set in this paper is based on [21]. It is chosen in the low range for amplitude $(400 \mathrm{mV})$ and frequency $(40 \mathrm{kHz})$ for a later energy harvester's application. Both feedback, $C_{f}$ and reference capacitance, $C_{r}$ is set fixed at $5 \mathrm{pF}$. The capacitance detection, $C_{x}$ is varied to the nominal value $C_{r}$ to get accepted linear range, of the changes of capacitance to the output voltage.

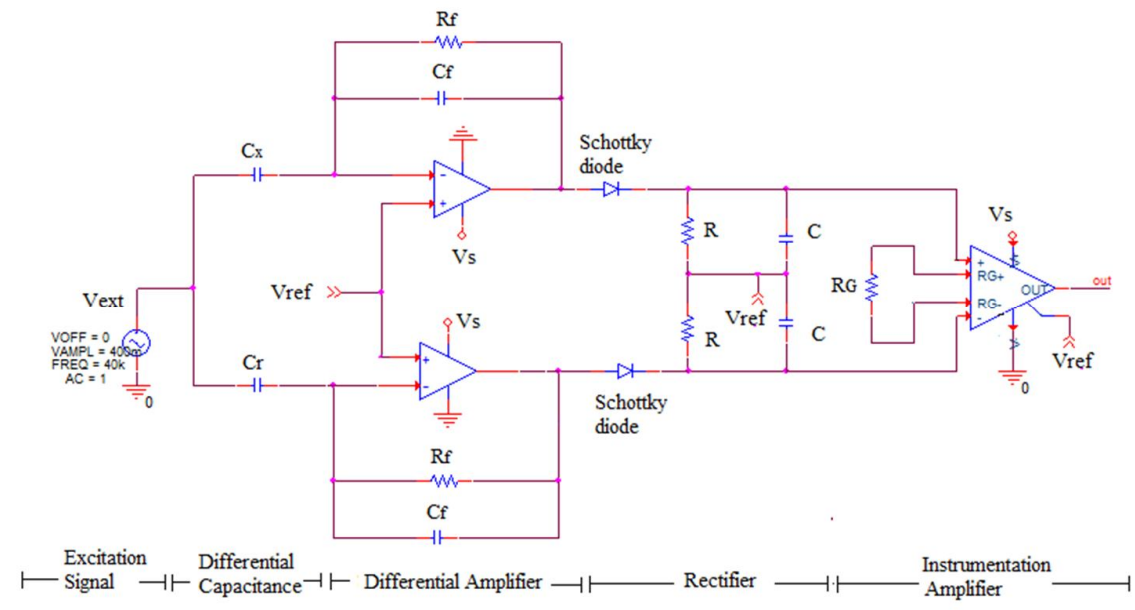

Fig. 3: Capacitance-to-voltage sensing circuit.

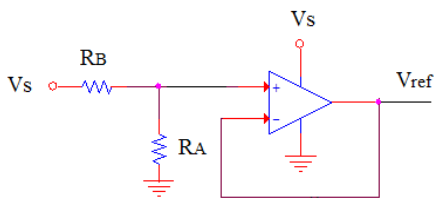

Fig. 4: Voltage divider with unity gain buffer.

In order to reduce the number of signal sources, a voltage divider is used to supply the reference voltage, $V_{\text {ref }}$ at near half the level of the signal source, $V_{s}$. Figure 4 shows the voltage divider with feedback connected to an inverting input amplifier to act as a unity gain buffer amplifier or voltage follower. The circuit consists of a pair of resistors connected in series to make a potential divider which feeds the divided signal source to the non-inverting input of the op-amp. The output voltage of the buffer is connected to the inverting input. The differential between two potentials is applied to the buffer differential input whose output is fed as a reference voltage to the reference input of the 
instrumentation amplifier, the non-inverting input of the differential amplifier and rectifier. The unity gain buffer can control the potential difference and stop any unwanted current from appearing across the pair of resistors.

According to Thevenin's law, $\mathrm{V}_{\text {ref }}$ is set as approximately half of Vs using the same value of resistors in $R_{A}$ and $R_{B}$

$$
V_{\text {ref }}=V_{S}\left(\frac{R_{A}}{R_{A} \cdot R_{B}}\right)
$$

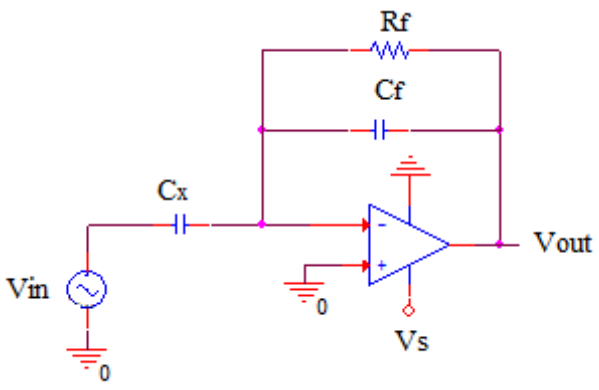

Fig. 5: Differential amplifier circuit with feedback $R_{f}$ and $C_{f}$.

The feedback loop of the differential amplifier consists of the feedback capacitor, $\mathrm{C}_{\mathrm{f}}$ in parallel with the resistor, $R_{f}$ as in Fig. $5 . R_{f}$ is added to reduce presence of small $\mathrm{dc}$ offset voltages at the input. The feedback value is chosen to be large enough in this work $\left(\mathrm{R}_{\mathrm{f}}=10 M \Omega\right)$ to overcome the sensitivity to noise problem that exists in the sensor circuit. For an ideal op-amp, the current flowing through the capacitor, $C \frac{d V_{i n}}{d t}$ is equal to the current flowing through the feedback loop, $\frac{V_{\text {out }}}{\left(R_{f}+Z_{C_{f}}\right)}$

The frequency domain analysis is obtained by expressing the impedance of the feedback components in the complex plane. The transfer function may be written as

$$
\frac{V_{\text {out }}}{V_{\text {in }}}=-\frac{Z_{f}}{Z_{C_{x}}}=-\frac{R_{f} \| \frac{1}{j \omega C_{f}}}{\frac{1}{j \omega C_{x}}}=-\frac{j \omega R_{f} C_{x}}{1+j \omega R_{f} C_{f}}
$$

From Eq. (2) we can derive that $V_{\text {out }}$ is proportional to the changes of $C_{x}+\Delta C$ in Eq. (3)

$$
V_{\text {out }}=-\frac{C_{x}+\Delta C}{C_{f}} \frac{1}{1+\frac{1}{j \omega R_{f} C_{f}}} V_{\text {in }}
$$

Having the advantage of very low forward voltage drop and ultrafast switching properties, a Schottky diode was chosen as a rectifier. In this work, we are using a 1N711 Schottky diode. It is suitable for very low power and high frequency applications. It has a very low reverse leakage current of $200 \mathrm{nA}$ at maximum reverse voltage, $\mathrm{V}_{\mathrm{r}}=50 \mathrm{~V}$. According to [21], $\mathrm{R}$ and $\mathrm{C}$ are chosen to satisfy the range of $\tau=\mathrm{RC}$ in $\mathrm{f}_{\text {ext }}{ }^{-1}<\tau<\mathrm{f}_{\mathrm{s}}{ }^{-1}$, where $f_{\text {ext }}$ is the frequency at common terminal of $C_{x}$ and $C_{r}$ while $f_{s}$ is the frequency at $C_{x}$. 
Finally, the resistor gain $R_{G}$ at the instrumentation amplifier is chosen according to $R_{G}=$ $100 \mathrm{k} \Omega /(\mathrm{G}-1)$ [22]. In this work, $R_{\mathrm{G}}=100 \mathrm{k} \Omega$ is selected to obtain a $\mathrm{G}=2$ gain from the Analog Device, AD623. All amplifiers used in this work are used as single supply amplifiers.

\section{RESULTS}

This work has used the power generated from an energy harvester board as its voltage supply of $3 \mathrm{~V}$ to power a capacitance sensing circuit. Figure 6 shows the output voltage for different capacitance value from $3.5 \mathrm{pF}$ to $12.5 \mathrm{pF}$. The capacitance sensing circuit consists of two amplifiers and one instrumentation amplifier with two Schottky rectifier diodes. An excitation supply signal of $400 \mathrm{mV}$ is supplied to the common differential terminal to check for a low excitation frequency of $40 \mathrm{kHz}$.

Results have shown a high level of linearity in the output voltage to capacitance variation as shown in Fig. 7. For nominal $5 \mathrm{pF}$, the output voltage can be summarized as in Eq. (4).

$$
V_{\text {out }}=0.13432 C_{x}+0.82832
$$

The output voltage is proportional to the change of capacitance sensing $\mathrm{C}_{\mathrm{x}}$ in $\mathrm{pF}$ range. Comparison of results is listed in Table 1.

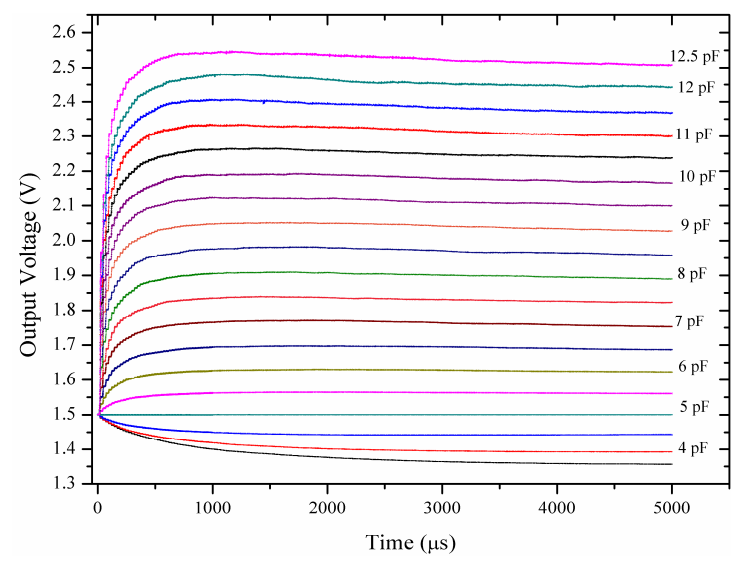

Fig. 6: Voltage output for capacitance value variation at nominal $5 \mathrm{pF}$.

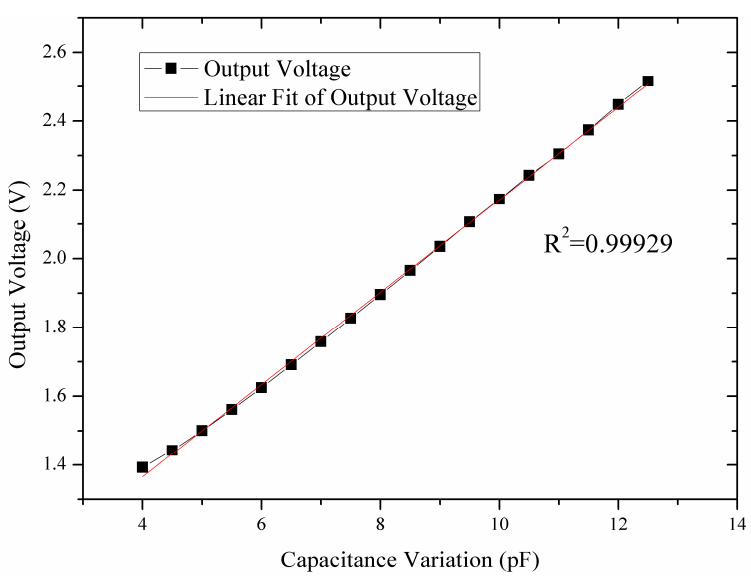

Fig. 7: High linearity performance of DC output circuit at nominal $5 \mathrm{pF}$. 
Table 1: Comparison of capacitance sensing work

\begin{tabular}{cccccc}
\hline Ref & $\begin{array}{c}\mathbf{C}_{\text {SENSE }} \\
{[\mathbf{p F}]}\end{array}$ & $\begin{array}{c}\text { DC Voltage } \\
{[\mathbf{V}]}\end{array}$ & $\begin{array}{c}\mathbf{P}_{\text {diss }} \\
{[\mathbf{m W}]}\end{array}$ & $\begin{array}{c}\text { Sensitivity } \\
{[\mathbf{m V} / \mathbf{f F}]}\end{array}$ & $\begin{array}{c}\text { Excitation Signal, } \\
\mathbf{V}_{\text {ext }}\end{array}$ \\
\hline$[21]$ & $4.99-5.01$ & $1.236-1.263$ & 5.384 & 1.32 & $400 \mathrm{mV}, 400 \mathrm{kHz}$ \\
This work & $4.00-12.5$ & $1.392-2.516$ & 3.900 & 0.132 & $400 \mathrm{mV}, 40 \mathrm{kHz}$ \\
\hline
\end{tabular}

\section{CONCLUSION}

Simulation results on the capacitance sensing circuit have shown that the proposed circuit is able to detect capacitance changes from 4 to $12.5 \mathrm{pF}$ capacitance range using a 3 $\mathrm{V}$ signal supply. The detected voltage is from 1.4 to $2.5 \mathrm{~V}$ using $400 \mathrm{mV}$ excitation sources with $40 \mathrm{kHz}$ frequency. The present results have shown that the circuit consumed $3.9 \mathrm{~mW}$ of power with a high level of linearity with R squared of 0.99929. Similar linear results were also valid for other nominal capacitance values (e.g: $1 \mathrm{pF}$ ). The simulated circuit has shown a high degree of sensitivity of $0.132 \mathrm{mV} / \mathrm{fF}$. In future, we hope to test the device for sending data wirelessly. Elimination of the excitation source can be done by realizing an oscillator circuit at the front-end of the CVC circuit in the future.

\section{ACKNOWLEDGEMENT}

This work was funded by the Exploratory Research Grant Scheme (ERGS13-0210054), Ministry of Higher Education Malaysia.

\section{REFERENCES}

[1] Kompis C, Aliwell S. (2008) Energy harvesting technologies to enable remote and wireless sensing. Sensors and Instrumentation KTN Report, 1-72.

[2] Krupenkin T. (2011) Method and apparatus for energy harvesting using microfluidics. US patent No. US007898096B1, 1-21

[3] Wang L, Yuan F. (2007) Energy harvesting by magnetostrictive material (msm) for powering wireless sensors in SHM. Proc. SPIE Sensors and Smart Structures Technologies for Civil, Mechanical, and Aerospace Systems, 1 - 11,

[4] Beeby S, Tudor M, White N. (2006) Energy harvesting vibration sources for microsystems applications. Measurement Sci. Tech., 17(12):R175-R195.

[5] Park G, Rosing T, Todd M, Farrar C, Hodgkiss W. (2008) Energy harvesting for structural health monitoring sensor networks. J. Infrastruct. Syst., 14(1):64-79.

[6] Kloub H, Hoffmann D, Folkmer B, Manoli Y. (2009) A micro capacitive vibration energy harvester for low power electronics. PowerMEMS 2009, Washington DC, USA, 165-168.

[7] Louisiana Tech University (2010) Shoe power generator, embedded in the sole of a shoe, harvest energy. Science Daily. Retrieved March 24, 2012, from http://www.sciencedaily.com /releases/2010/04/100426113137.htm.

[8] Krupenkin T, Taylor J. (2011) Reverse electrowetting as a new approach to high-power energy harvesting. Nature Communications, 2(448):1-7.

[9] Cottone F. (2011) Introduction to vibration energy harvesting [PowerPoint slides]. Retrieved from http://wwwnipslab.org/files/file/nips\%20summer\%20school\%202011/Cottone\%20Introducti on\%20to\%20vibration\%20harvesting.pdf.

[10] Harrop P, Das R. (2009) Energy harvesting and storage for electronic device 2009-2019. IDTechEx Report. 
[11] Zhu D, Beeby S, Tudor J, White N, Harris N. (2010) A novel miniature wind generator for wireless sensing applications. IEEE Sensors, 1-4. Retrieved from http://eprints.soton.ac.uk/271682/.

[12] Sharma S. (2012) Estyle buyers' guide: Your prescription to the right tablet. Electronics for You, 44(2):88-92.

[13] Sharma S. (2012) Embedded: touch screens what's the latest? Electronics for You, 44(2): 69-72.

[14] Viehweger C, Baldauf M, Keutel T, Kanoun O. (2012) Hybrid energy harvesting for autonomous sensors in building automation. Proc. IEEE Int. Instrum. Measure. Tech. Conf. (I2MTC 2012), 610-613.

[15] Kuehne I, Frey A, Eckstein G, Schmi U, Seidel H. (2006) Design and analysis of a capacitive vibration-to-electrical energy converter with built-in voltage. Solid-State Device Research Conference, 36:138-141.

[16] Stevens Institute of Technology Miniature (2010) Energy harvesting technology could power wireless electronics. Science Daily. Retrieved March 22, 2012, from http://www.sciencedaily.com/releases/2010/07/100709131308.htm.

[17] Edamoto M, Suzuki Y, Kasagi N, Kashiwagi K, Morizawa Y, Yokoyama T, Seki T, Oba M. (2009) Low-resonant-frequency micro electret generator for energy harvesting application. Proc. IEEE Int. Conf. MEMS 2009, Sorrento, 1059-1062.

[18] Sterken T, Baert K, Puers R, Borghs G, Mertens R. (2003) A new power MEMS component with variable capacitance. Pan Pacific Microelectronic Symposium 2003, 27-34.

[19] Arakawa J, Suzuki Y, Kasagi N. (2004) Micro seismic power generator using electret polymer film. Fourth Int. Workshop on Micro and Nanotechnology for Power Generation and Energy Conversion Applications, 187-190.

[20] Kuehne I. (2008) Power MEMS - a capacitive vibration-to-electrical energy converter with built-in voltage. Sensors and Actuators A: Physical (142)1:263-269. doi:10.1016/j.sna.2007.02.036.

[21] Haider MR, Mahfouz MR, Islam SK, Eliza SA, Qu W, Pritchard E. (2008) A low-power capacitance measurement circuit with high resolution and high degree of linearity., Midwest Symposium on Circuits and Systems, 261-264.

[22] Analog Devices. (1997-2008) AD623: Single-Supply, Rail-to-Rail, Low Cost Instrumentation Amplifier. [Online]. Available: www.analog.com/media/en/technicaldocumentation/data-sheets/AD623.pdf [retrieved Oct 22, 2015] 